\title{
The Change of Space Use of Shared Space from Landed to High- Rise Settlement
}

\author{
Ayuko Setyo Adiyanti ${ }^{1, *}$, Ardhya Nareswari ${ }^{2}$, and Alexander Rani Suryandono ${ }^{2}$ \\ ${ }^{1}$ Student, Department Architecture and Planning, Faculty of Engineering Gadjah Mada University, Indonesia. \\ ${ }^{2}$ Lecturer, Department Architecture and Planning, Faculty of Engineering Gadjah Mada University, Indonesia.
}

\begin{abstract}
Indonesia is entering an era of urban settlement transformation from horizontal landed living settlement to low-rise settlement, into the construction of vertical high-rise settlement. This resulted in the landed settlement residents that being moved to high-rise settlement, they have encountered a change of high-rise vertical living culture that different from their living culture before. This study aims to find out the use of shared space in landed living and high-rise settlement. The research method used in this research is qualitative descriptive study. The site of the research is in the landed settlement of Kampung Pulo and the high-rise settlement of Jatinegara Barat. Kampung Pulo settlement is a residence of Jatinegara Barat residents before they are moved. The result of the research shows the change of space use for shared space from landed to high-rise settlement; (1) landed settlement more accommodate the diversity of communal activities than high- rise settlement. (2) in the landed settlement there is a territory transition space that accommodates the needs of interaction, homebased business activities, and play, whereas high-rise settlement there is no more transition space, so the need for interaction and play is contained in the public space, while the trading activities needs are mostly found within the private area. (3) In landed settlements, the shared space used for communal activities is more multifunctional than high rise settlement.
\end{abstract}

Keywords: landed settlement, high-rise settlement, space use change.

\section{Introduction}

Indonesia is entering an era of urban settlement transformation from horizontal landed living settlement to low-rise settlement, into the construction of vertical high-rise settlement. This resulted in the landed settlement residents that being moved to high-rise settlement, they have encountered a change of high-rise vertical living culture that different from their living culture before. After being transferred to new settlement, some residents from Kampung Pulo have limited space to perform their daily activities. As a result, some activities such as selling, visiting, playing, and gathering, are carried in spaces that should not be used for such activities. this study will examine the change of space use of shared space from landed to high-rise settlement.

\section{Literature Review}

\section{Space for Communal Activity}

Shared space is a room function that always exist in Indonesian society. The existence of shared space is a symbol of the community, especially in a settlement, which has good relationships with others, marked by the communality. Shared space is a space that accommodates various communal activities of community (both positive and negative) from the economic,social, and cultural needs.

\section{Kampong Pulo}

Kampung Pulo is a very high density settlement like any other slums area in Indonesia. With an area of $8 \mathrm{Ha}$, the majority of the existing site is almost entirely utilize for building development. Residents of Kampung Pulo who live on the banks of the river and in the middle of the settlement almost entirely affected by the annual flood, so most of the housing in this area has 2 floors height.

\section{Jatinegara Barat flat}

Jatinegara barat Flats is located in Jatinegara Barat, about 300 meters from Kampung Melayu Terminal, intended to accommodate Kampung Pulo relocation which has been moved from Ciliwung River since June 2015. The Jatinegara Barat Flat consists of two towers, 16 floors, with housing capacity reaching 520 units.

\section{Qualitative Methods}

Research with qualitative methods that use qualitative approach aims to reveal events or facts, circumstances, phenomena, variables and circumstances that occur when 
research takes place by presenting what really happened.

\section{Sample Collecting Technique}

\section{Observation}

Observation is a method of collecting data through direct observation in the field, the purpose of obtaining various concrete data in the research location.

\section{Interview}

The technique of interview according to Nazir (1988) is the process of obtaining data for research purposes by way of question and answer face to face between researchers and respondents.

\section{Research Methods}

This research uses qualitative method with descriptive approach. Research with qualitative methods that use qualitative approach aims to reveal the events, facts, circumstances, phenomena, variables and circumstances that occur when research takes place by presenting what really happened.

\section{Data Collecting Methods}

\section{Primary Data}

Primary data were collected by field observations, interviews with sources, as well as documentation in the field.

\section{Secondary Data}

Secondary data collection was conducted with the study of literature records, study results, and the results of previous research publications related to the title of this study.

\section{Research Focus}

The object of this study are landed settlement and high-rise flats. Based on variables used in some similar research, the variables that match the topic of space observation used for shared activities are; physical conditions of space, activities that occur, actors activities, frequency of activities, and space attributes.

\section{Research Object}

The research object is located in the landed settlement of Kampong Pulo and the Jatinegara Barat high-rise flat. The problem of frequent floods, resulting in residents inhabited in less decent housing. Floods not only harm the people of Kampung Pulo that have direct contact with the river Ciliwung, but also affected the entire village of Kampung Pulo is located far from the banks of the river Ciliwung. That is why, there is similar habit activities and culture between residents who live on the riverbank and on the village.
Because of that, this research took place at landed settlement in Kampung Pulo that did not experience river normalization.

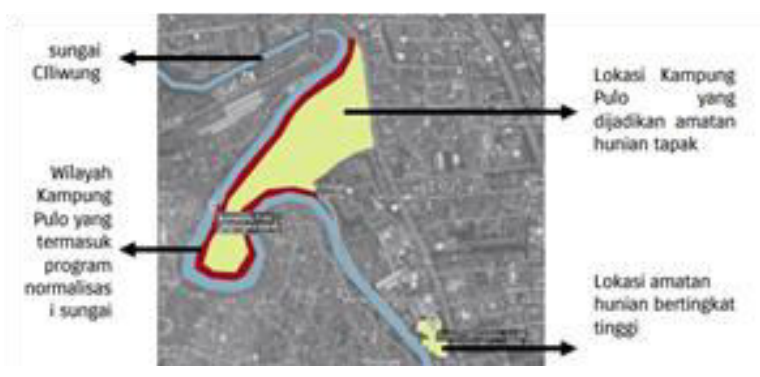

Fig. 1. Research Object.

\section{Kampong Pulo Observation Results}

\section{Alleys at landed settlement in Kampong Pulo}
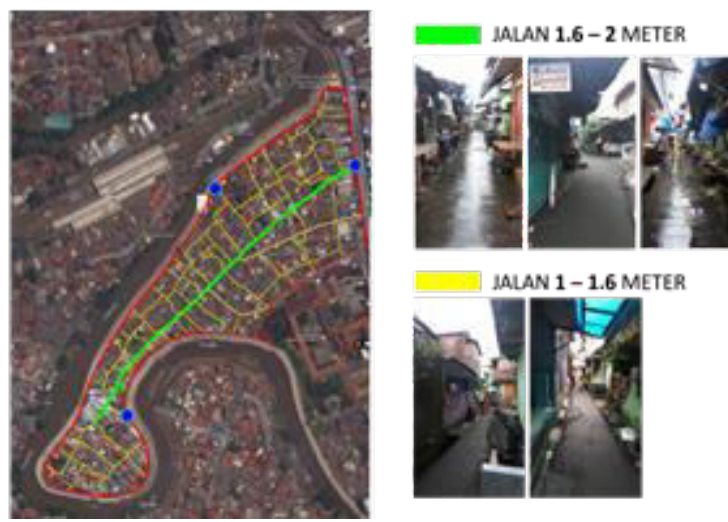

Fig. 2. Kampong Pulo Alleys.

The observations started from a few alley (blue circle) located on the banks of the Ciliwung river and on the edge of Jatinegara Barat street. There are two types of alleys in Kampung Pulo, the main alley (green) cuts the middle of Kampung Pulo area measuring 1.6-2 meters which can be passed by people and vehicles such as motorcycles and bicycles by passing each other. While the other alley branch (colored yellow) measuring 1-1.6 meters and can only be passed by a bike or people walking without passing..

\section{Kampong Pulo's Characteristics}

Node A

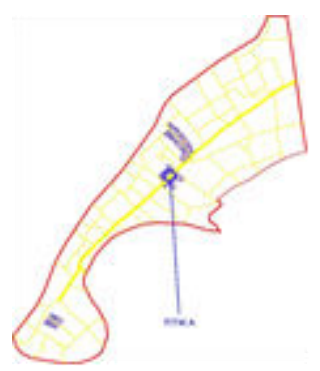

Fig. 3. Node A. 
Node A is located in the middle of Kampung Pulo, at this point there is a buying and selling activity. In the hallway room measuring 1.8 meters with right-left alleyway there is a concrete covered drain, the placement of merchandise is placed in the right-left of the alley that is precisely above the concrete covered drains. When the buying and selling activity did not happen, there are trading tables that are left outside the stalls, but some are storing it back into the house.
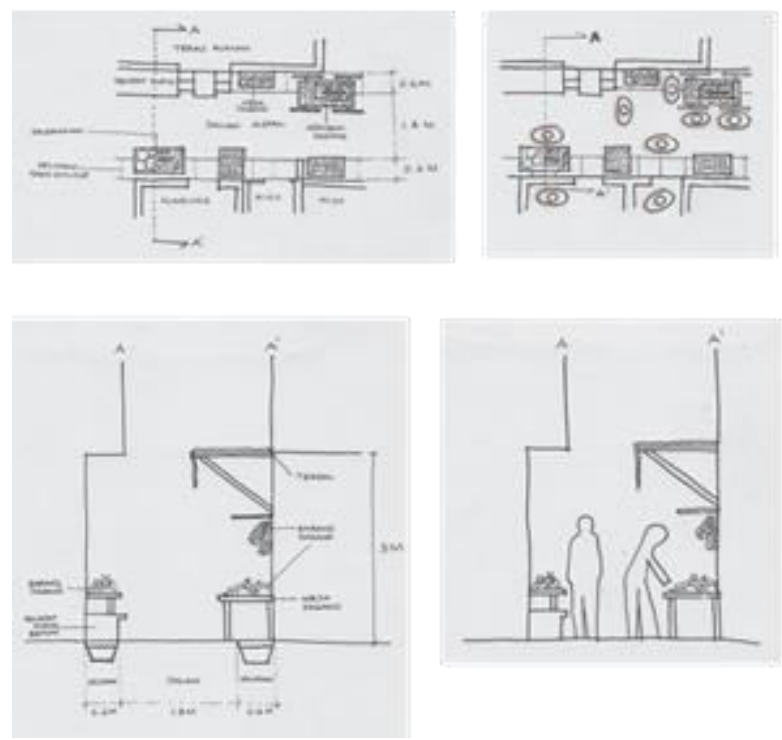

Fig. 4. Space Attributes.

\section{Node B}

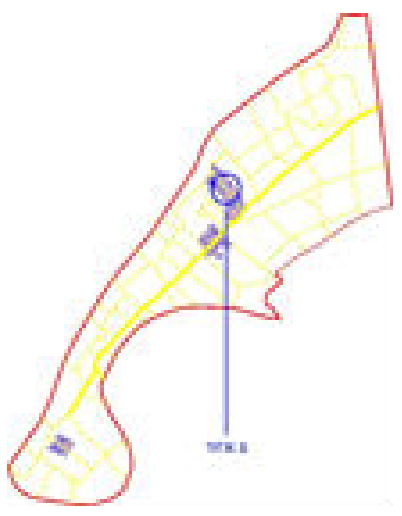

Fig. 5. Node B.

At node B, there are shared activities shown by the presence odong-odong traders who enlivened by the presence of children who plays and accompanied by parents who live in the house around. Odong-odong carts are parked in a rather wide location, usually they are looking for a vacant house that can be visited temporarily. Ceramic chairs in most homes are indeed made for relaxing chatting with neighbors.

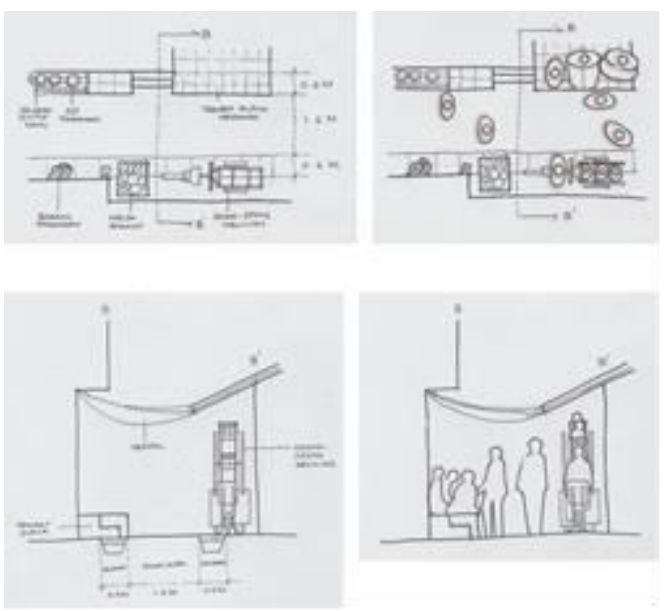

Fig. 5. Space Attributes at Node B.

Node C

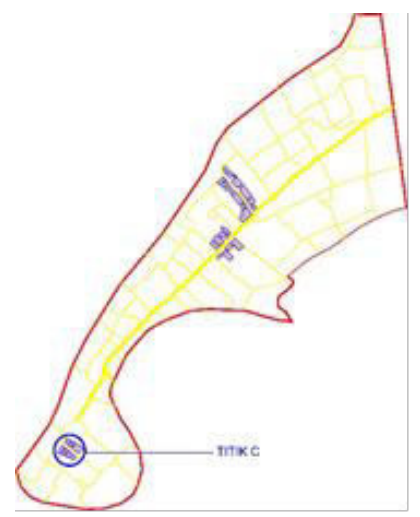

Fig. 7. Node C.

At node $\mathrm{C}$ there is activity such as communication with neighbors, some used to be sitting on chair, some other are usually just interact at front of houses without using any chair at all. Different home positions that go back and forth towards the alley are used as storage space, such as merchandise and parking of two-wheeled vehicles.
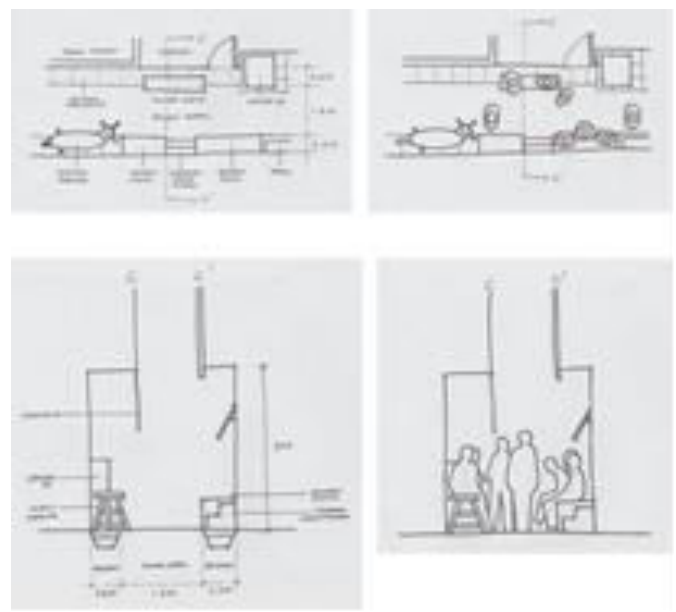

Fig. 8. Space Attributes at Node C. 


\section{Interview Result}

Interviews and filling questionnaires were conducted on 17 respondents from Kampung Pulo residents. Of the 17 respondents, each with details of 9 people mothers, 5 fathers, 1 teenager and 2 children. The interview was conducted with the aim of asking some questions to the Kampung residents related to the profile of the residents of Kampung Pulo, the points of the tendency of people gathered, public space facilities available in Kampung Pulo. While charging questionnaires related to the verification of literature review data on the joint activities conducted by residents of Kampung Pulo. The results of the interviews show that some of the residents of Kampung Pulo are IDKs from DKI since birth, points of joint activity in alley, guard post, front of house and resident's house.

\section{Observation Summary}

\section{Use of shared space for social activities}

Some concrete seats are used as a place for casual conversation between the neighbors, the reason they choose to chat casually on the terrace because of the wide limitations of their homes. So entertaining guests and chatting with a comfortable neighbor is performed on the terrace.

\section{Use of shared space for transactional activities}

There are several types of selling in Kampung Pulo, the most common type is the type of selling on the terrace. The property trademark is dominated by the type of trade placed on the porch or front of the house. As for the type of selling in the house, which can only be performed by a residence that has large enough room to store the merchandise, and merchandise offered in the form of grocery stalls for everyday purposes.

\section{Use of shared space for kids play}

Child playroom takes place on the terrace of the house, street alley, vacant lot, field, game rental, and odong-odong game of traveling traders. Limitations of space and land resulted in children looking for land that they could use as a place to just talk about running, or playing bikes.

\section{Jatinegara Barat Flat Observation Results}

\section{Ground Floor}

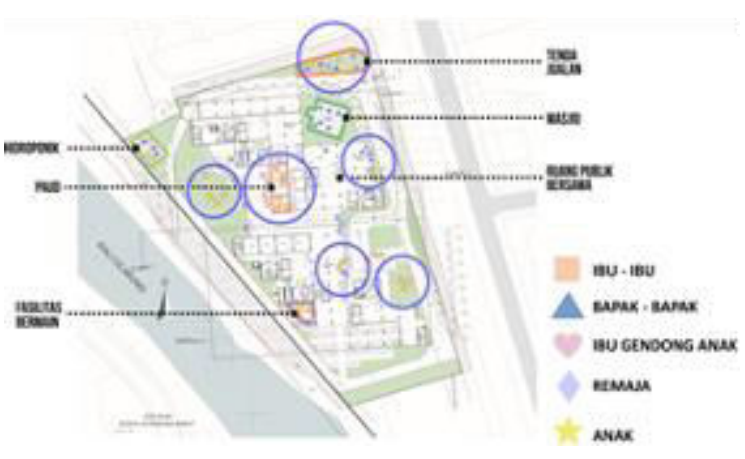

Fig. 9. Space Use at Ground Floor.

Shared activities on the 1st floor are scattered at some point, most of the residents choose to sit by the steps of entrance entrance. Groups of gangs consist of fathers, mothers to adults, some other mothers accompany their children in early childhood while talking to parents, there are also children playing in the back garden towers and mothers ktivitas together spread in some point, most of the residents choose to sit at the edge of the stairs entrance entrance.

Groups of gangs consist of fathers, mothers to adults, some other mothers accompany their children in early childhood while talking to parents, there are also children playing in the back garden towers and mothers who keep chatting while.

\section{Second floor}

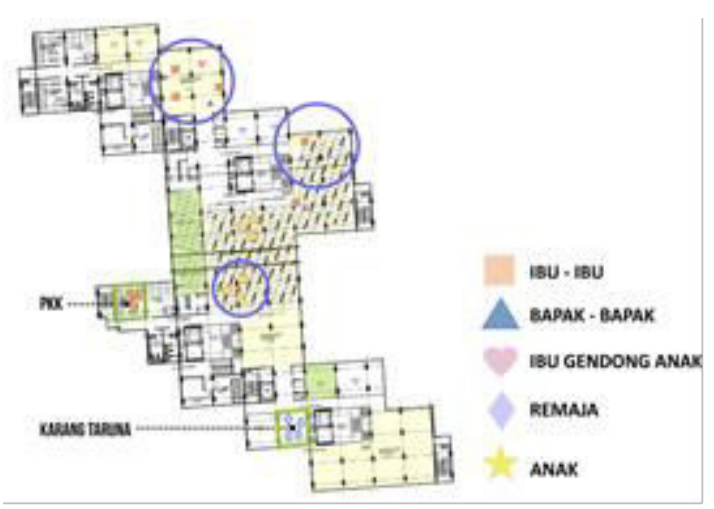

Fig. 10. Space Use at Second Floor.

The shared activity was done in several selling stalls, but because the kiosks were not so much, so the joint activity that happened was not so intense, while the activity was done by many children just running or playing badminton in the area together. 


\section{Typical floor}

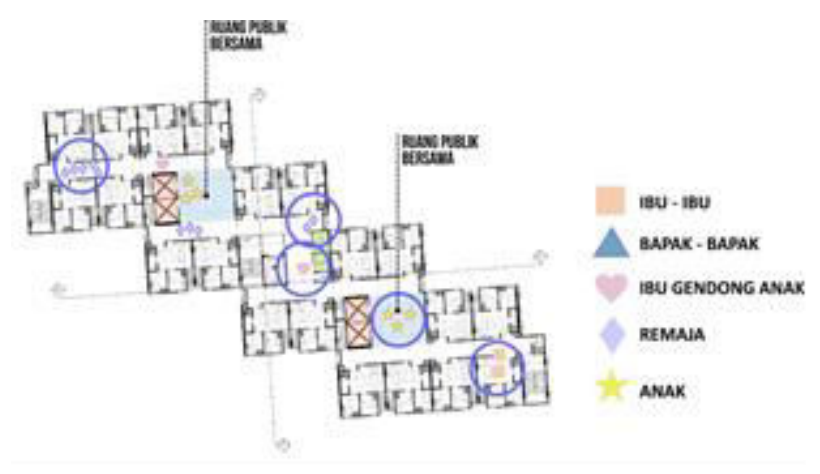

Fig. 11. Space Use at Typical Floor.

The typical floor of Jatinegara tower which is designated as residential floor, in the public area of the corridor and lobby lift is not every time used by many citizens. In everyday life, the elevator front lobby that serves as a public space together is not used. The space is used for the social gathering room of the mothers or the residents of the community every month, sometimes the children also cycling and running in the vestibule of the elevator. Actually has provided children's playroom and facilities on the 1st floor, but due to its location is far enough so that children choose to play near their residential units, and parental supervision is much more monitored through their residential units.

On a typical floor there are different rules. If on the 1st and 2nd floors is a floor intended for public activities, then a typical 14-storey is prohibited for public activities such as trade. Here's an overview of the rules that apply on typical floors:

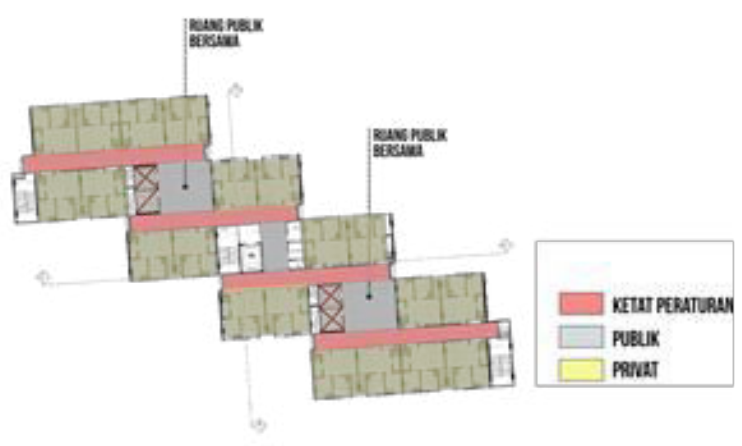

Fig. 12. Space Use Regulation at Typical Floor.

\section{Interview Results}

Jatinegara Barat Flats consists of 2 towers, namely tower A and tower B. From both towers are taken sample of respondents to be interviewed about the profile of residents of Jatinegara Barat Flats, the points tendency of people gathered in the tower area, public space facilities provided in flat, as well as additional questions about neighboorhood relationships, a market that becomes merchant buyers, and playground locations. Respondents from tower A counted to 27 people, while from tower B counted to 19 people. seller on the door of the North who made the respondents amounted to 4 people. In addition to several residents and sellers, one of the managers of the Jatinegara Barat Flats named Mr. Sarkim Sukarya as Head of Sub Division Housing Jatinegara Barat Flats was also interviewed related to the profile data of towers and shared space facilities provided.

The results of the interviews of this Jatinegara Barat Flat, among others; the work of most residents in the field of informal flat, co-existing facilities in the towers are on the 1st and 2nd floor, neighboorhood relationships are reduced compared to when living in Kampung Pulo, many people who work as traders and choose to sell in residential units and doors North on the 1st floor compared to the 2nd floor provided by the tower management as a public space for selling, and more children playing on typical floor corridors around their residential units.

\section{Observation summary}

\section{Use of shared space for social activities}

Shared activities gathered among the neighbors are more prevalent on the 1st floor in the public space area near the entrance stairs. In the area consists of groups of youth, fathers and even mothers who huddle to sit back together. Elsewhere, PAUD's front room and children's playground behind the towers are also used as chat rooms for mothers who are waiting for their children to play. North door selling arena is also quite crowded buyers from offices around the towers. While on the 2nd floor, communication between neighbors is not so happening because at least the stalls selling on the 2 nd floor. Some people go by to buy things they need but not linger. Some children are seen playing in the 2nd floor public area. Similar to the 2nd floor, a typical floor also appears to be few people who gather together. Some children play together or play bicycles in front of the elevator, but for the fathers and mothers not many are seen clustering together..

\section{Use of shared space for transactional activities}

There are 3 places that use to become selling area provided for jatinegara barat residents. Such as selling in residential units, on the 2 nd floor and at the north door. Here are the details:

Table 1. Flats Residents that Work at Informal Sector.

\begin{tabular}{lc}
\hline \multicolumn{1}{c}{ Trade location } & total \\
\hline Residential units & 53 \\
Second floor & 12 \\
North gate & 31 \\
Total sellers & 96 \\
\hline
\end{tabular}

Source: author

\section{Use of shared space for kids play}

The Jatinegara barat flats have provided a children's playground on the 1st floor on the West side of the tower, but unfortunately most users are from the floor near the ground floor. While the children who live upstairs, more likely to play in the front elevator area and corridor at each floor. 

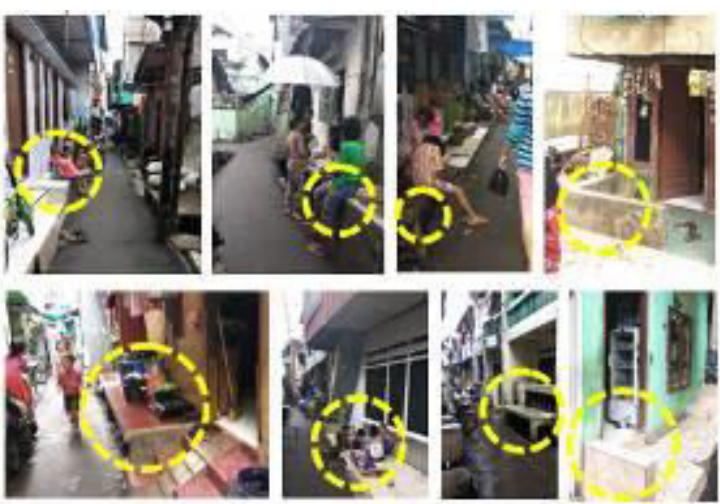

Fig. 13. Seating Provided at Landed Housing Kampong Pulo.
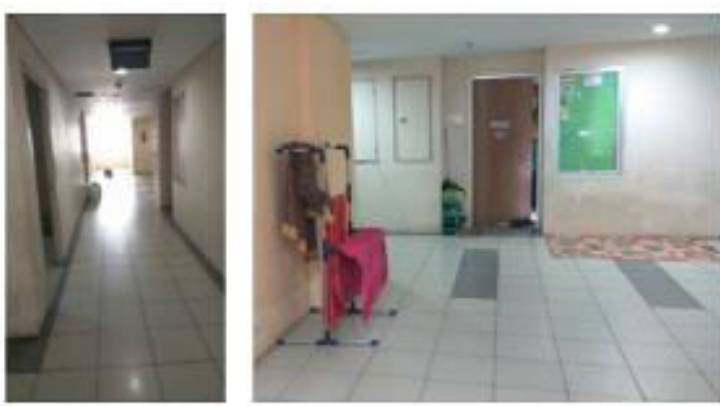

Fig. 14. Seating did not Provided at Flats Corridors.

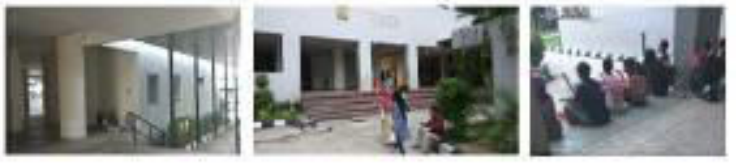

Fig. 15. Entrance Area for Sitting and Sosializing.

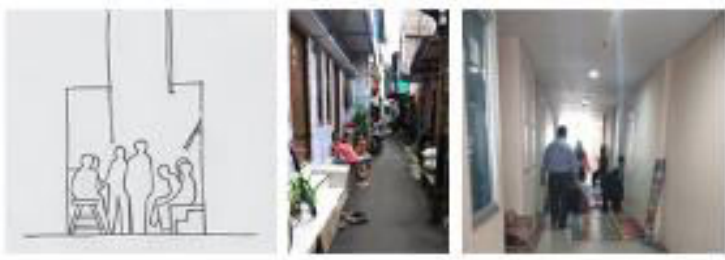

Fig. 16. Seating at landed housing kampong Pulo.
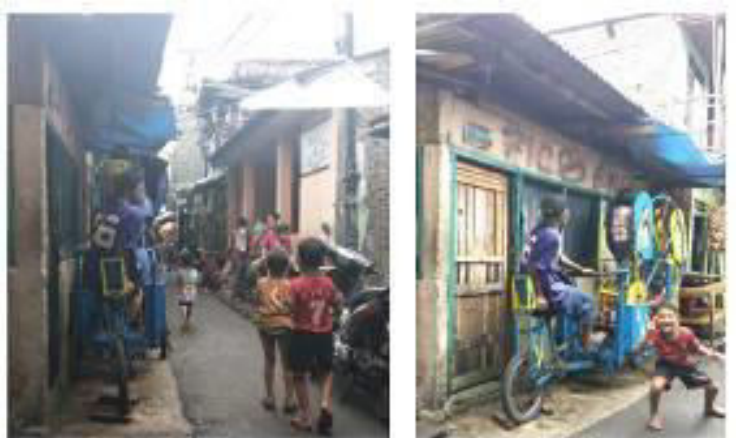

Fig. 17. Activity Supporting Element at Kampong Pulo.

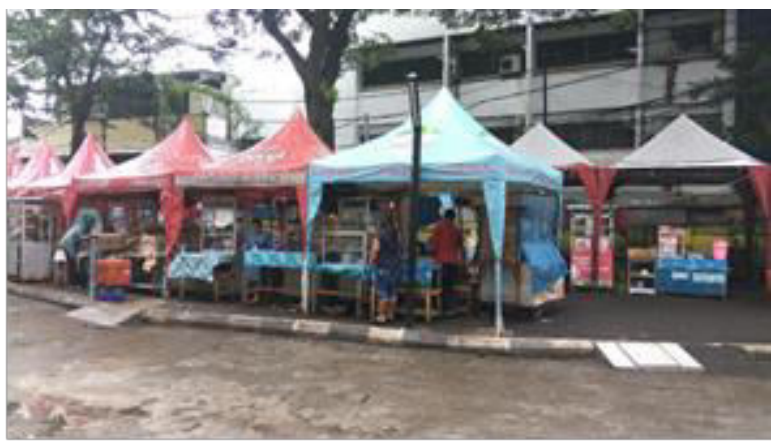

Fig. 13. Some Traders at North Gate Jatinegara Barat Flats.

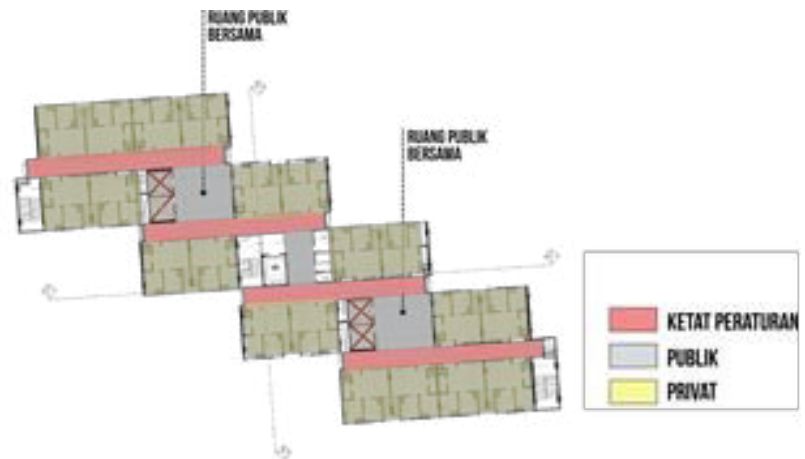

Fig. 13. Space regulation at Jatinegara Barat Flats.
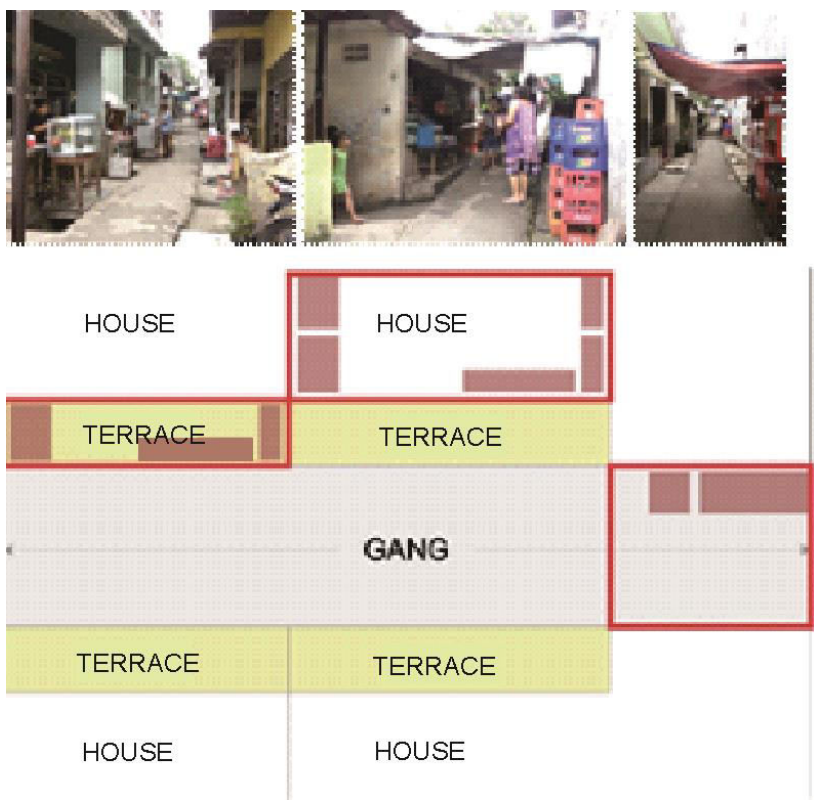

Fig. 13. Shared space use illustration at kampong pulo.

In contrast to the Jatinegara Barat Flats, most dominated by the form of 'trade-in' area type. Apparently this relates to enforcement of existing regulations, it causes pressure on the occupants who want to trade and expanding into the dwelling whose purpose is to avoid enforcement of regulations by the manager / management of towers. 


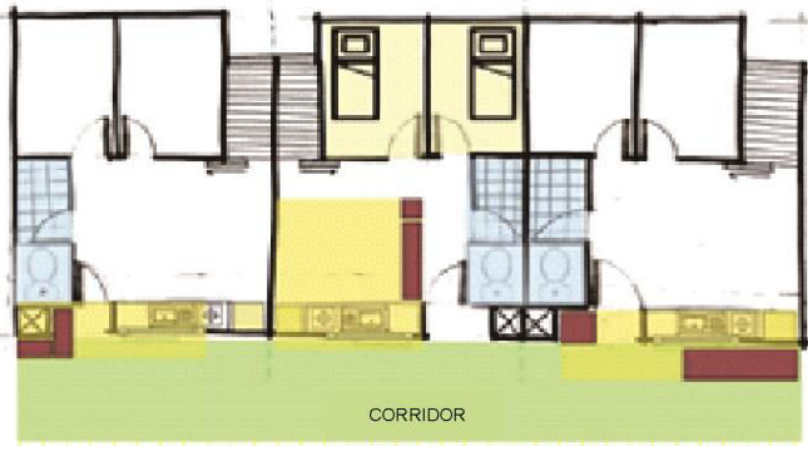

Fig. 13. Type of Trading Area at Residential Unit in Jatinegara Barat Flats.

\section{Conclusion}

\section{Change of space use for shared space from landed to high-rise settlement}

1) Landed settlement accommodate more diversity of shared activities rather than high-rise settlement. in Kampung Pulo, various kinds of shared activities occur in many common spaces, whereas in Jatinegara Barat flat, some variety of shared activities only occurs on the 1 st floor.

2) In the landed house, there is a transition area such as terrace that accommodates the needs of interaction, trade, or play. In contrast to high-rise occupancy, there is no longer found transition space because of space limitation, so the need for interaction is only occur in the public space, while the needs of trading are mostly found in private areas.

3) Spaces used for shared activity in landed settlement are more multifunctional, it is different from high-rise settlement because every space is only used for 1 activity function.

\section{References}

Altman, I. (1975) The Environment and Social Behavior. Monterey, CA: Wadsworth.

Ananto, Sofian D. (2015). Adaptasi Teritorialitas pada Permukiman Horisontal ke dalam Permukiman Vertikal. Temu Ilmiah IPLBI 2015.

Darmiwati, Ratna. (2000). Studi Ruang Bersama dalam Rumah Susun Bagi Penghuni Berpenghasilan Rendah. Dimensi Teknik Arsitektur 28(2). 114-122.

Dwiputra, Citra. (2009). Konsep Perencanaan dan Perancangan Rumah Susun Sederhana Sewa di Surakarta. Skripsi S1 Universitas Sebelas Maret.

Fitrie Aisyah dan Evawani Ellisa. (2013). Pengaruh Elemen Lungkungan Terhadap Interaski Social Di Ruang Public Hunian Kampung Adat Penduduk. FT UI. 2013

Haryadi \& Setiawan, Bakti. (1995). Arsitektur Lingkungan dan Perilaku : Teori, Metodologi dan Aplikasi. Proyek Pengembangan Pusat Studi Lingkungan, Direktorat
Jenderal Pendidikan Tinggi, Departemen Pendidikan dan Kebudayaan Republik Indonesia.

Madanipour, A. (1996). Urban design and dilemmas of space. Environment and Planning D: Society and Space 14, 331-355.

Najib, Mochammad., Ramdlani, Subhan., dan Asikin, Damayanti. (2015). Ruang Bersama Kampung Temenggungan Ledok Malang. Jurnal Mahasiswa Jurusan Arsitektur 3(1)

Nasution, Ivan K. dan Mediatrich Triani. (2012). Kecerdasan Ruang Marjinal dan Potensi Ruang Publik. Proceding Temu Ilmiah IPLBI, 21-24.

Ningsi, Sari Widya. (2014). Perluasan Bangunan Perumahan Swadaya sebagai Ruang Fungsi Hunian dan Usaha Kota Makassar. Tesis Pascasarjana Universitas Hasanuddin Makassar.

Novitika Sari, Hendria. (2010). Hubungan Antara Persepsi terhadap Pemanfaatna Ruang Publik dengan Penyesuaian Sosial Penghuni Rumah Susun. Skripsi S1 Universitas Muhammadiyah Surakarta.

Purwanto, Edi. dan Wijayanti. (2012), Pola Ruang Komunal di Rumah Susun Bandaharjo Semarang. 39(1). 23-30.

Rakodi, C. (2002). Urban Livelihoods A People-Centred Approach To Reducing Poverty. Earthscan, London.

Rifqi Ihsan, Faris. (2014). Pola Penggunaan Ruang Komunal di Kampung Deret, Tanah Tinggi, Kecamatan Jogar Baru, Jakarta Pusat. Tesis Pascasarjana Universitas Indonesia.

Shalih, Osmar. (2012). Adaptasi Penduduk Kampung Melayu Jakarta terhadap Banjir Tahunan. Skripsi, Fakultas MIPA, Departemen Geografi. Universitas Indonesia.

Siema, Jesieca And Michael Tedja, M.T., Ir. And Indartoyo, M.T., Ir. (2013). Peremajaan Pemukiman Kampung Pulo Dengan Pendekatan Perilaku Urban Kampung. Undergraduate Thesis, Binus.

Sitorus, Freddy Masito. (2015) Fleksibilitas Pemanfatan Ruang pada Permukiman Rawa Banjir Kampung Pulo, Jakarta Timur. Tesis Pascasarjana Universitas Gadjah Mada.

Suminar, El Yanno. (2016). Kampung Vertikal Kalianyar dengan Pendekatan Arsitektur Perilaku. Skripsi S1 Universitas Sebelas Maret.

Sunaryo, R.G (2004) Penataan Ruang Publik Yang Memadukan Pola Aktivitas Dengan Perubahan Fisik Kawasan, Kasus Kawasan Tambak Bayan - Babarsari, Yogyakarta, Seminar \& Lokakarya Nasional Ikatan Arsitek Indonesia, Jakarta.

Sunaryo,Rony Gunawan and Soewarno,Nindyo and Ikaputra,and Setiawan, Bakti. (2010). Posisi Ruang Publik dalam Transformasi Konsepsi Urbanitas Kota Indonesia. In: Seminar Nasional Bidang Ilmu Arsitektur dan Perkotaan:Morfologi Transformasi dalam Ruang Perkotaan yang Berkelanjutan, Universitas Diponegoro, Semarang, Indonesia.

Yasmin. (2009). Pola Pemanfaatan Ruang pada Perumahan Massal Vertikal sebagai Refleksi Gaya Pemanfaatan 
Ruang Bersama. Disertasi S3 Universitas Pendidikan Indonesia.

Zega, Nifka Ulrico Giovanni. (2015). Rumah Susun Sederhana Sewa di Denpasar. Skirpsi S1 Universitas Udayana. 